\title{
Accumulation and Distribution Characteristics of Zinc and Cadmium in the Hyperaccumulator Plant Sedum plumbizincicola
}

\author{
Dong Cao ${ }^{1,2}$, Hongzheng Zhang ${ }^{2}$, Yaodong Wang ${ }^{3}$, Leina Zheng ${ }^{4 *}$ \\ ${ }^{1}$ Civil and Environmental Engineering School, University of Science and Technology \\ Beijing, Beijing 100083, China; Chinese Academy for Environmental Planning, \\ Beijing 100083, China \\ ${ }^{2}$ Chinese Academy for Environmental Planning, Beijing 100083, China \\ ${ }^{3}$ School of Botany, The University of Melbourne, Victoria 3010, Australia \\ ${ }^{4}$ Key Laboratory of Soil Environment and Pollution Remediation, Institute of Soil \\ Science, Chinese Academy of Sciences, Nanjing 210008, China
}

\begin{abstract}
Accumulation and distribution of $\mathrm{Zn}$ and $\mathrm{Cd}$ in the hyperaccumulator plant Sedum plumbizincicola were investigated in a hydroponic experiment. Mean Cd and $\mathrm{Zn}$ concentrations in shoots (7010 and $18400 \mathrm{mg} \mathrm{kg}^{-1}$ ) were about 7- and 5-fold higher than those in roots ( 840 and $3000 \mathrm{mg} \mathrm{kg}^{-1}$ ) after exposure to $100 \mu \mathrm{M} \mathrm{CdSO}_{4}$ and $600 \mu \mathrm{M} \mathrm{ZnSO}_{4}$, respectively. Cd and $\mathrm{Zn}$ concentrations in young leaves (4330 and $9820 \mathrm{mg} \mathrm{kg}^{-1}$ ) were about 6- and 2-fold higher than those in mature leaves (636 and $2620 \mathrm{mg} \mathrm{kg}^{-1}$ ), respectively. MicroPIXE analysis showed that $\mathrm{Zn}$ was predominantly localized in epidermal cells in both young and mature leaves, but large amounts of $\mathrm{Zn}$ occurred in mesophyll cells in young leaves. Leaf tissue fractionation showed that soluble and cell wall fractions were different at the two stages of leaf growth. Young and mature leaves of S. plumbizincicola also showed different accumulation and distribution characteristics for $\mathrm{Zn}$ and $\mathrm{Cd}$.
\end{abstract}

Key words: Hyperaccumulator, Heavy metal, Localization, Leaf age, Micro-PIXE

\section{Introduction}

Zinc ( $\mathrm{Zn})$ and cadmium $(\mathrm{Cd})$ are two ubiquitous inorganic contaminants in soils and waters (Nriagu and Pacyna 1988). Phytoextraction, the use of metal-accumulating plants to remove pollutants from soils by concentrating them in harvestable parts, is considered to be a cost-efficient and environmentally friendly method for removal of metals from contaminated soils in situ (McGrath et al. 2002; Schwartz et al. 2003). Accumulation of $\mathrm{Zn}$ and $\mathrm{Cd}$ has been studied in several candidate plant species. $\mathrm{Cd}$ concentrations in different parts of Bidens pilosa L. followed the sequence leaves > stem > roots > flowers (Sun et al. 2009). Zn accumulation in both Agropyron cristatum plant shoots and roots increased with total soil $\mathrm{Zn}$ concentrations, and $\mathrm{Zn}$ concentrations in roots were always greater than in shoots (Lin et al. 2013). Sridhar et al. (2005) and Küpper et al. (1999) found that the Zn concentrations in Brassica juncea and Noccaea caerulescens (formerly Thlaspi caerulescens) were higher in mature leaves than in young leaves.

Various mechanisms have been proposed to explain the tolerance of plants to metal contamination. A wide range of defense mechanisms have apparently evolved including metal exclusion, active excretion, restricted distribution of toxic metals to

*Corresponding to: Leina Zheng, Phone: 0086-25-86881128; e-mail: 1hwu0603@aliyun.com, lnzheng@issas.ac.cn. 
sensitive tissues, metal binding to cell walls, chelation by organic molecules and compartmentalization in vacuoles (Vögeli-Lange and Wagner 1990). Vacuolar sequestration and cell wall binding may play a major role in hyperaccumulation of metals, and these mechanisms are involved in metal tolerance, transport and storage in plants (Frey et al. 2000). For the $\mathrm{Cd} / \mathrm{Zn}$ hyperaccumulator Noccaea praecox, $\mathrm{Cd}$ preferentially accumulates with high concentrations of $\mathrm{Cl}^{-}$in vacuoles of large vacuolated epidermal cells, here bound mainly to oxygen-based (O)-ligands (Koren et al. 2013). Cd was found mainly at the margins of leaves in $N$. caerulescens by Cosio et al. (2005). In low Cd treatments, younger leaves exhibited higher $\mathrm{Cd}$ concentrations than older ones, but the reverse was true at high $\mathrm{Cd}$ treatments.

Sedum plumbizincicola, (Family: Crassulaceae) has been reported by Wu et al. (2013) to be a new $\mathrm{Zn}$ and $\mathrm{Cd}$ hyperaccumulator native to China However, there have so far been no investigations of $\mathrm{Zn}$ and $\mathrm{Cd}$ accumulation and cellular distribution in $S$. plumbizincicola according to leaf position, within the leaf tissue or at the cellular level. Micro Proton-Induced X-ray Emission (microPIXE), a reliable technique for providing unique information on the spatial element distribution, was employed in the present study. With its list-mode-analysis, PIXE offers the highest sensitivity and accuracy in performing elemental mapping and quantification of the data extracted from arbitrarily selected micro-areas. It has been employed for elemental localization within plant tissues (Ager et al. 2002; Vogel-Mikuš et al. 2008). Objectives of this study were to quantitatively investigate the accumulation and distribution of $\mathrm{Zn}$ and $\mathrm{Cd}$ in S. plumbizincicola. Collected information should enhance our understanding of the biochemical mechanisms involved in $\mathrm{Zn}$ and $\mathrm{Cd}$ phytoextraction. Cellular and subcellular metal distribution within plant organs and tissues may also be good indicators of detoxification and tolerance mechanisms.

\section{Materials and Methods}

Seeds of S. plumbizincicola were germinated on vermiculite moistened with deionized water for the first two weeks and then with a basal nutrient solution for the following four weeks ( $\mathrm{Li}$ et al. 2013). The basal nutrient solution ( $\mathrm{pH}$ 5.8) contained $\mathrm{Ca}\left(\mathrm{NO}_{3}\right)_{2}$ 1.0, $\mathrm{MgSO}_{4} 0.5, \mathrm{~K}_{2} \mathrm{HPO}_{4}$ 0.5, $\mathrm{KCl} 0.1$, MES 1.0, and $\mathrm{KOH} 0.5 \mathrm{mM}$; and $\mathrm{H}_{3} \mathrm{BO}_{3} 10$, $\mathrm{Na}_{2} \mathrm{MoO}_{4}$ 0.2, $\mathrm{MnSO}_{4}$ 1.8, $\mathrm{CuSO}_{4}$ 0.31, $\mathrm{NiSO}_{4} \cdot 6 \mathrm{H}_{2} \mathrm{O}$ 0.5, Fe-EDDHA 100, and $\mathrm{ZnSO}_{4} 10 \mu \mathrm{M}$. Healthy and equal-sized seedlings were then transplanted into nutrient solution for metal treatments. There were three treatments: (1) control (basal nutrient solution containing $10 \mu \mathrm{M} \mathrm{Zn}$ ); (2) basal nutrient solution $+100 \mu \mathrm{M} \mathrm{CdSO}_{4}$; and (3) basal nutrient solution $+600 \mu \mathrm{M} \mathrm{ZnSO}_{4}$. Each treatment was replicated three times. Each vessel contained $2 \mathrm{~L}$ of nutrient solution and three seedlings. The treatment solutions were renewed every three days. Based on preliminary tests, plants could grow well at these concentrations without any visible metal toxicity symptoms. Germination and plant culture were performed in a growth chamber with a 14-hour daylength and an irradiance of $60 \mathrm{Wm}^{-2}$ supplied by fluorescent tubes, a $25^{\circ} \mathrm{C} / 20^{\circ} \mathrm{C}$ (day/night) temperature regime and 60-70\% humidity. Nutrient solutions were aerated continuously and renewed every four days. Experimental plants were harvested after $96 \mathrm{~h}$ exposure to metal treatment. Shoots were rinsed with deionized water and separated into young leaves (5 leaves from the apex of the primary stem), mature leaves (2 leaves from the base of the primary stem), stems, and roots. Sample young and mature leaves were used for $\mu$ PIXE analysis described below. Metals adsorbed on the root surface were exchanged with $5 \mathrm{mM}$ EDTA-Na $\mathrm{Na}_{2}$ solution (Li et al., 2013). 
Plant samples were oven-dried at $80^{\circ} \mathrm{C}$ and then digested with concentrated $\mathrm{HNO}_{3}-\mathrm{HClO}_{4}(3: 2, \mathrm{v} / \mathrm{v})$. Concentrations of $\mathrm{Zn}$ and $\mathrm{Cd}$ in the digests were determined using a flame atomic absorption spectrophotometer (FAAS) (Varian SpectrAA 220 FS, Varian Inc, Palo Alto, CA). A certified reference material (GBW07603, provided by the Institute of Geophysical and Geochemical Exploration, Langfang, Hebei Province, China) was used for quality control. Data obtained by the methods above were within the certified ranges of $\mathrm{Zn}$ and $\mathrm{Cd}$ (data not shown), indicating that the analysis of the metal concentrations was reliable.

Fresh young and mature leaves were cut into pieces (about $5 \times 5 \mathrm{~mm}$ ) and then stacked on a carbon tab (PST-AI023). The other side of the carbon tab was attached to plastic foam and connected with a plastic holder. Leaf tissue was then pressed gently on a strip of aluminum which was partially immersed in liquid nitrogen before being fully immersed in liquid nitrogen. This contact freezing method ensured that leaf material was frozen quickly to prevent curling and protect the structure of the leaf tissue. The cryo-fixed leaf tissue was then dried in a freeze drier (Emitech K750X, UK) for $72 \mathrm{~h}$. Freeze-dried leaf tissues were hand sectioned using clean razor blades under a dissecting microscope. Selected sections were mounted on carbon tabs and then placed on a standard aluminum-frame sample holder. Prior to $\mu$ PIXE analysis, plant samples were examined and photographed using a dissecting microscope (Leica MZ FLIII).

The High Energy Heavy Ion Microprobe of Australian Nuclear Science and Technology Organisation (ANSTO) was used to examine elemental distribution in the leaves of $S$. plumbizincicola. A $3 \mathrm{MeV}$ beam energy was focused on the sample areas with a beam width of about $3 \mu \mathrm{m}$ and current between 0.5 and $1 \mathrm{nA}$. X-rays were measured with a high-purity Ge detector. A $100 \mu \mathrm{m}$ Mylar foil was used to reduce low energy X-rays and thus pile-up in the PIXE spectrum. Zn mapping and analysis of $\mu$ PIXE spectra were performed using the GeoPIXE II software package (Chris Ryan, CSIRO, pers. comm.). Quantitative analysis was standardless and has been described in detail by Ryan et al. (1990a, b). Error estimates were extracted from the error matrix generated in the fit (Ryan et al. 1990a), and minimum detection limits (MDLs) were calculated using the Currie formula (Currie, 1968). Quantitative point analysis (QPA) was performed by drawing area transects across leaf $\mathrm{Zn}$ maps and then generating $\mathrm{Zn}$ distribution profiles across area transects. Transects were localized on the basis of visual inspection of elemental maps and light microscopic images to provide an elemental profile across leaf sections (Kachenko et al. 2008).

S. plumbizincicola plants were collected from an old $\mathrm{Pb} / \mathrm{Zn}$ mine area in the suburbs of Hangzhou city, Zhejiang province, east China. Healthy and equal-sized shoots (about $5 \mathrm{~g} \mathrm{FW}$ and about $6 \mathrm{~cm}$ high) were grown in the basal nutrient solution for two weeks. Then $\mathrm{Zn}(10$ and $600 \mu \mathrm{M})$ and $\mathrm{Cd}(1$ and $100 \mu \mathrm{M})$ treatments were set up with three replicates. Plants were harvested after a four week metal exposure. Shoots were rinsed with deionized water and separated into young leaves and mature leaves as before. A differential centrifugation technique according to Weigel and Jäger (1980) and Gabbrielli et al. (1990) with some modification was used for subcellular fractionation. Fresh leaves $(2 \mathrm{~g})$ were homogenized in pre-cooled extraction buffer containing $50 \mathrm{mM}$ Tris- $\mathrm{HCl}(\mathrm{pH} 7.5), 250 \mathrm{mM}$ sucrose and $1.0 \mathrm{mM} \mathrm{C}_{4} \mathrm{H}_{10} \mathrm{O}_{2} \mathrm{~S}_{2}$. Cells were separated into three fractions: cell wall, soluble fraction, and organelle fraction with different centrifugation. The cell wall and organelle fractions were then digested 
with concentrated $\mathrm{HNO}_{3}-\mathrm{HClO}_{4}(3: 2, \mathrm{v} / \mathrm{v})$. $\mathrm{Zn}$ and $\mathrm{Cd}$ concentrations in the different fractions were determined by FAAS.

Data were analyzed by one-way Analysis of Variance using SPSS version 13.0 software for Windows. Data are summarized as means \pm standard errors (S.E.M.). Differences in metal concentrations between treatments were analyzed by Duncan's Multiple Range tests at the 5\% probability level.

\section{Results and Discussion}

Differences in $\mathrm{Cd}$ and $\mathrm{Zn}$ concentrations were found between the various parts of $S$. plumbizincicola after exposure to $100 \mu \mathrm{M} \mathrm{CdSO}_{4}$ or $600 \mu \mathrm{M} \mathrm{ZnSO}$ for 96 hours (Fig. $1)$. The concentrations of $\mathrm{Cd}$ and $\mathrm{Zn}$ in the bulk shoots $(7010 \pm 1250$ and $18400 \pm 3500$ $\left.\mathrm{mg} \mathrm{kg}{ }^{-1}\right)$ were about 7 and 5 times higher than those in the roots $(840 \pm 71$ and $3000 \pm 600 \mathrm{mg} \mathrm{kg}^{-1}$ ), respectively. The ranking with respect to both $\mathrm{Cd}$ and $\mathrm{Zn}$ concentrations was young leaves > stems $>$ mature leaves and roots. Young leaves accumulated approximately 4-6 times higher concentrations of $\mathrm{Cd}(4330 \pm 1220 \mathrm{mg}$ $\left.\mathrm{kg}^{-1}\right)$ and $\mathrm{Zn}\left(9820 \pm 2560 \mathrm{mg} \mathrm{kg}^{-1}\right)$ than mature leaves $\left(636 \pm 76,2620 \pm 910 \mathrm{mg} \mathrm{kg}^{-1}\right)$ in the elevated $\mathrm{Cd}$ and $\mathrm{Zn}$ treatments; this was also the case in the respective control treatments. Preferential accumulation of $\mathrm{Cd}$ and $\mathrm{Zn}$ in young leaves was consistent with previous studies which have demonstrated $\mathrm{Cd}$ in the main stems was readily transported to the branch and young leaves rather than the mature leaves (Hu et al. 2013). The vigorous transpiration and physiological processes in young tissue may be an explanation.

Localization of $\mathrm{Zn}$ in young and mature leaves was studied further using micro-PIXE spectrometry (Fig. 2). PIXE maps showed that in young leaves, $\mathrm{Zn}$ was mainly localized in the epidermis and in several layers of mesophyll near the epidermis, whereas in the mature leaves it was predominantly localized in the epidermal cells (Figs. 2b, e). QPA profiles showed Zn concentration in the upper epidermis of both young and mature leaves reached approximately $15 \mathrm{~g} \mathrm{~kg}^{-1}$. In the mesophyll, $\mathrm{Zn}$ concentrations varied between 4 to $9 \mathrm{~g} \mathrm{~kg}^{-1}$ in young leaves, whereas it was below $2 \mathrm{~g}$ $\mathrm{kg}^{-1}$ in mature leaves. Zn concentration in vascular bundles was slightly higher or similar to those in the surrounding mesophyll cells. PIXE maps also indicated higher $\mathrm{Zn}$ concentrations in the leaf margins in both young and mature leaves (Figs. 2b, e).

Storage of $\mathrm{Cd}$ and $\mathrm{Zn}$ in different subcellular compartments was quantified using the differential centrifugation technique procedure (Fig. 3). Cd and $\mathrm{Zn}$ concentrations in various subcellular fractions increased with increasing $\mathrm{Cd}$ and $\mathrm{Zn}$ treatments. $\mathrm{Cd}$ distribution patterns between cell wall, organelle and soluble fractions were similar for the two different $\mathrm{Cd}$ concentrations tested in both young and mature leaves (Fig. 3a). Cd concentration in young leaves was always higher than in mature leaves, which is in agreement with the data shown in Fig. 1a. Concentrations of $\mathrm{Cd}$ in both cell wall and organelle fractions were higher than in the soluble fraction. $\mathrm{Zn}$ distribution patterns between cell wall, organelle and soluble fractions were different for the young and mature leaves after exposure to $600 \mu \mathrm{M} \mathrm{ZnSO}$ for 4 weeks (Fig. 3b). $\mathrm{Zn}$ concentrations did not differ significantly between the three fractions in young leaves but did in mature leaves. Here the soluble fraction had the highest $\mathrm{Zn}$ concentration, the organelle fraction was intermediate, and the lowest concentration was found in the cell wall fraction. 


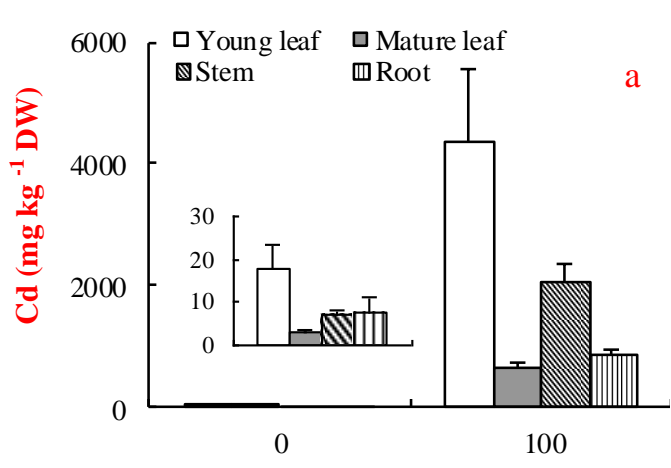

Cd in nutrient solution $(\mu \mathrm{M})$

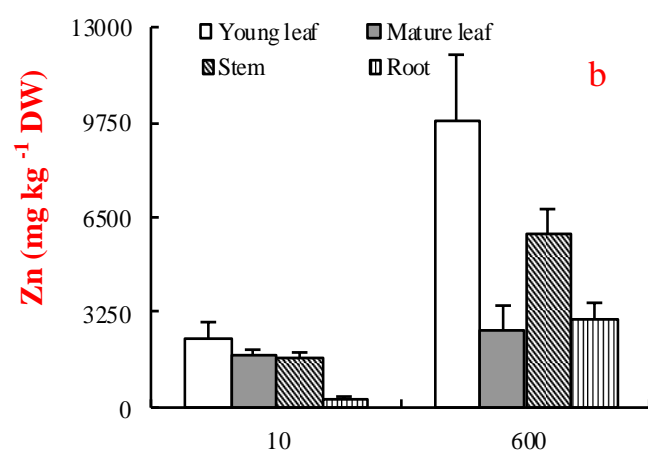

Zn in nutrient solution $(\mu \mathrm{M})$

Fig. $1 \mathrm{Cd}$ (a) and $\mathrm{Zn}$ (b) concentrations in young leaves, mature leaves, stems and roots of $S$. plumbizincicola after cultivation in hydroponics with different concentrations of Cd and Zn. Data are mean \pm S.E.M, $n=3$.
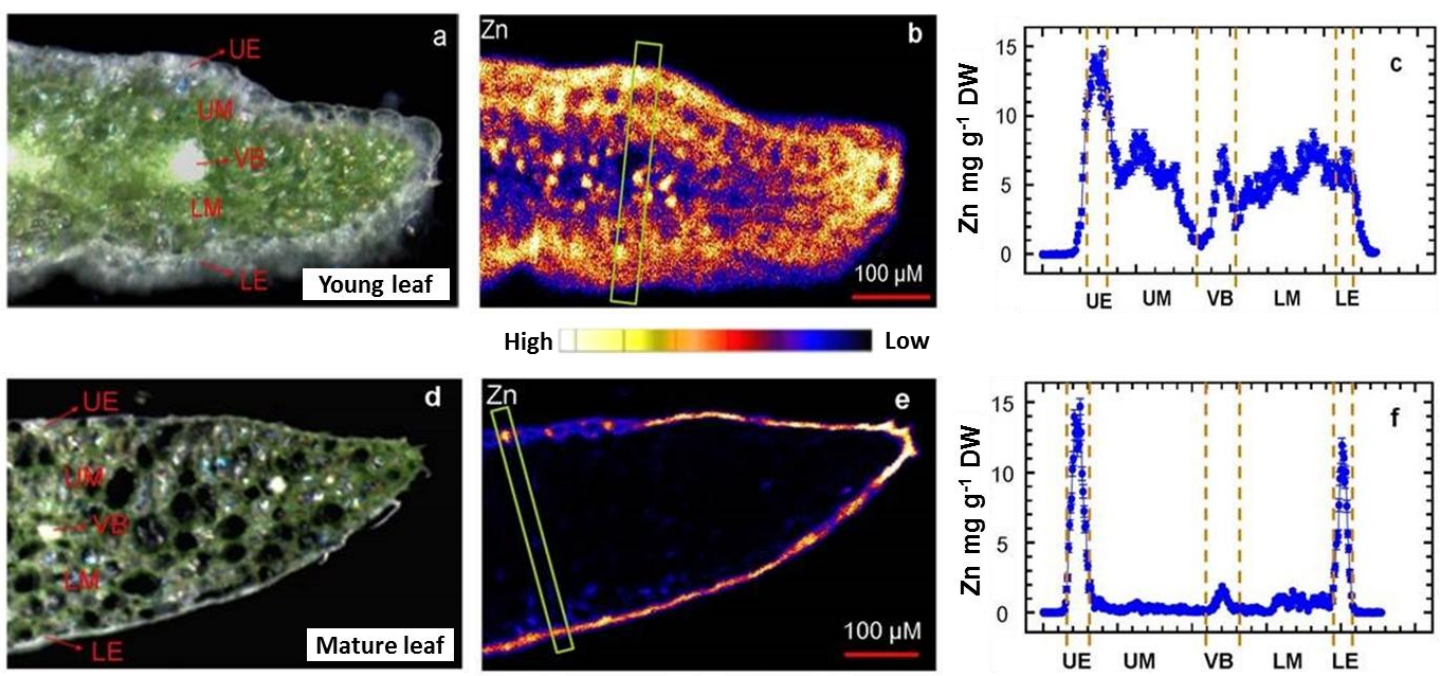

Fig. 2 Light microscope images (a, d), Zn PIXE maps (b, d) and quantitative point analysis (QPA) profiles (c, f) showing $\mathrm{Zn}$ distribution in cross sections of freeze-dried cryo-fixed young (left) and mature (right) leaves of $S$. plumbizincicola exposed to $600 \mu \mathrm{M} \mathrm{ZnSO}$. UE, UM, VB, LM and LE indicate upper epidermis, upper mesophyll, vascular bundle, lower mesophyll and lower epidermis, respectively. QPA profiles (c, f) are derived from micro-PIXE analysis across area transects outlined in green $(b, e)$, respectively; error bar indicates standard error of $\mathrm{Zn}$ concentrations at each point.
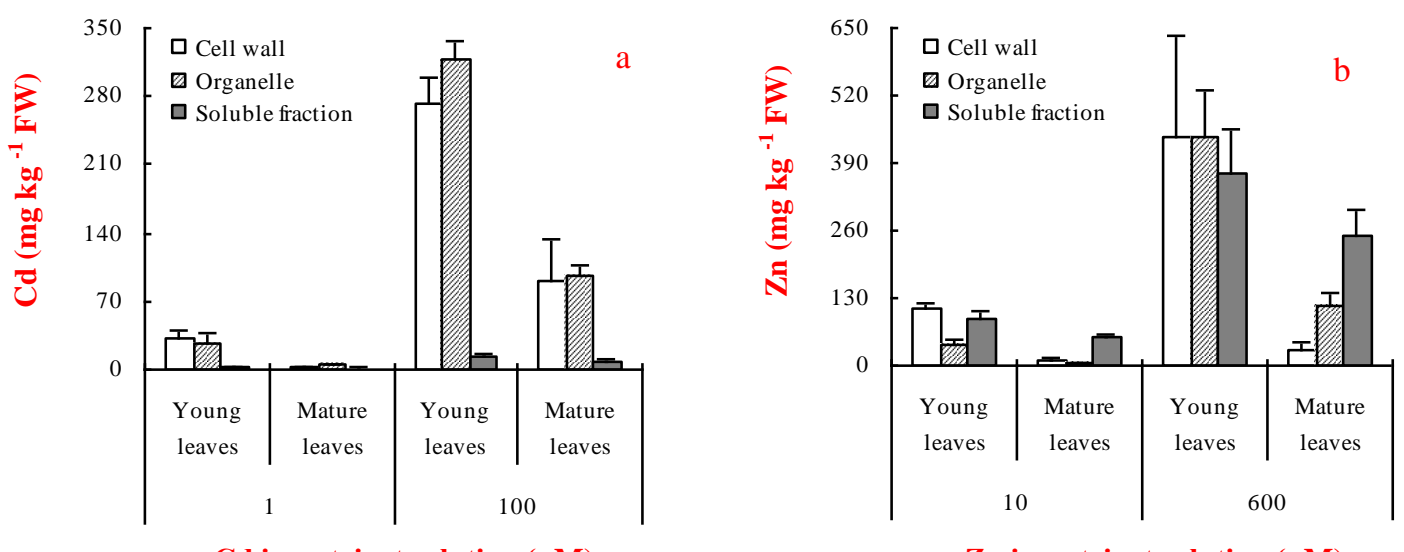

Fig. 3 Concentrations of $\mathrm{Cd}$ (a) and $\mathrm{Zn}$ (b) in the cell wall, organelle and soluble fractions of young and mature leaves of $S$. plumbizincicola after cultivation in hydroponics with different concentrations of $\mathrm{Cd}$ and $\mathrm{Zn}$. Data are means $\pm \mathrm{SE}, \mathrm{n}=3$. 
The distribution pattern of a toxic metal at the cellular and subcellular levels of leaves is considered to be an important strategy for metal tolerance and accumulation in plants (Krämer 2010). Compared to the mesophyll where the photosynthesis occurs, the physiological activity in the epidermis is less. Numerous studies have demonstrated that $\mathrm{Zn}$ and $\mathrm{Cd}$ are preferentially accumulated in the epidermis of leaves in many plant species, such as hyperaccumulators $N$. caerulescens, $N$. praecox, $P$. griffithi and the accumulators B. juncea, $S$. vulgaris (Küpper et al. 1999; Vogel-Mikuš et al. 2008; Hu et al. 2009; Sridhar et al. 2005; Chardonnens et al. 1998). Using PIXE, the current study also found a preferential localization of $\mathrm{Zn}$ in the epidermis of young and mature leaves of $S$. plumbizincicola. This could therefore be an important mechanism for metal tolerance and accumulation in $S$. plumbizincicola. However, a different distribution pattern of $\mathrm{Zn}$ in the mesophyll was found between young and mature leaves, in addition to a preferential accumulation of $\mathrm{Cd}$ and $\mathrm{Zn}$ in young leaves. Compared to mature leaves, a higher concentration of $\mathrm{Zn}$ was located in the mesophyll. Küpper et al. (2000) also found that higher concentrations of $\mathrm{Zn}$ occurred in mesophyll cells than epidermal cells in leaves of the hyperaccumulator Arabidopsis halleri. Tian et al. (2011) also found that $\mathrm{Cd}$ was preferentially accumulated in the mesophyll of the hyperaccumulator Sedum alfredii. It has been suggested that $\mathrm{Zn}$ accumuluation is associated with variation in cell size (Küpper et al. 2000). A highly significant correlation between the relative $\mathrm{Zn}$ concentrations in epidermal cells and their length was found in the leaves of $N$. caerulescens (Küpper et al. 1999). However, in A. halleri higher concentrations of $\mathrm{Zn}$ occurred in mesophyll cells than in epidermal cells, perhaps due to the small size of the vacuoles in the latter. The higher concentrations of $\mathrm{Zn}$ accumulation in the mesophyll of the young leaves of S. plumbizincicola might be partly explained by cell size effects. Additionally, the degree of tissue differentiation between mesophyll and epidermis in the newly-developed leaf might be less than in mature leaves. These results suggest that different detoxification mechanisms might exist in young and mature leaves of $S$. plumbizincicola.

At the subcellular level, a different distribution pattern of $\mathrm{Zn}$ was also found between young and mature leaves of $S$. plumbizincicola, with concentrations following the sequence: soluble fraction > organelle > cell wall in mature leaves but there were no significant differences between fractions in young leaves. Li et al. (2006) reported that subcellular $\mathrm{Zn}$ distribution in leaves of $S$. alfredii was in the order: cell wall fraction > soluble fraction $>$ cell organelles, suggesting the cell wall and vacuole play an important role in $\mathrm{Zn}$ tolerance and hyperaccumulation. This finding is not consistent with current study results. For $\mathrm{Cd}$, the cell wall and organelle fraction were the main fractions for both young and mature leaves of S. plumbizincicola. This is not consistent with reports for other plants. For example, in N. caerulescens, $\mathrm{Cd}$ is mostly localized in the apoplast with little in the vacuoles (Vázquez et al. 1992). In Bechmeria nivea, between 48-62\% of the element was localized in cell walls, 30-38\% in the soluble fraction, and the lowest percentage in the cellular organelles (Wang et al. 2008). Plant cell walls are composed mainly of polysaccharides (mainly cellulose, hemicellulose and pectin) and proteins, providing carboxyl, hydroxyl, amino and aldehyde groups (Hayens 1980) all of which can bind $\mathrm{Cd}$ ions and restrict their transport across membranes. The soluble fraction consists of mostly vacuoles (Gabbrielli et al. 1990) and acts as the subdominant site for preferential Cd binding in all test tissues. However, sulphur-rich peptides and organic acids are essential for the 
transport and storage of $\mathrm{Cd}$ in the vacuoles (Lichtenberger and Neumann 1997). Furthermore, the $\mathrm{Cd}$ increase in the organelles is most likely due to the preferential accumulation of $\mathrm{Cd}$ in chloroplasts (Ramos et al. 2002).

In conclusion, accumulation and distribution characteristics of $\mathrm{Zn}$ and $\mathrm{Cd}$ were different between young and mature leaves of $S$. plumbizincicola. Young leaves accumulated higher concentrations of $\mathrm{Zn}$ and $\mathrm{Cd}$ than mature leaves. MicroPIXE analysis showed that $\mathrm{Zn}$ was localized predominantly in the epidermal cells of both young and mature leaves, but large amounts of $\mathrm{Zn}$ were found in the mesophyll cells of young leaves. Leaf tissue fractionations showed that soluble and cell wall fractions were different in young and mature leaves. Further studies on the mechanisms of $\mathrm{Zn}$ and $\mathrm{Cd}$ hyperaccumulation in young and mature leaves of S. plumbizincicola are required.

Acknowledgements This work was jointly supported by the National Natural Science Foundation of China (41271326), the Chinese Academy for Environmental Planning, and AINSE awards (AINGRA 08079). We thank Professor AJM Baker (Universities of Melbourne and Brisbane, Australia) for his help in improving this paper.

\section{References}

Ager FJ, Ynsa MD, Dominguez-Solis JR, Gotor C, Respaldiza MA, Romero LC (2002) Cadmium localization and quantification in the plant Arabidopsis thaliana using micro-PIXE. Nucl Instrum Meth B 189:494-498

Chardonnens AN, ten Bookum WM, Kuijper LDJ, Verkleij JAC, Ernst WHO (1998) Distribution of cadmium in leaves of cadmium tolerant and sensitive ecotypes of Silene vulgaris. Physiol Plantarum 104:75-80

Cosio C, DeSantis L, Frey B, Diallo S, Keller C (2005) Distribution of cadmium in leaves of Thlaspi caerulescens. J Exp Bot 56:756-775

Currie LA (1968) Limits for qualitative detection and quantitative determination: application to radiochemistry. Anal Chem 40:586-593

Frey B, Keller C, Zierold K, Schulin R (2000) Distribution of Zn in functionally different leaf epidermal cells of the hyperaccumulator Thlaspi caerulescens. Plant Syst Evol 23:675-687

Gabbrielli R, Pandolfini T, Vergnano O, Palandri MR (1990) Comparison of two serpentine species with different nickel tolerance strategies. Plant Soil 122:271-277

Hayens RJ (1980) Ion exchange properties of roots and ionic interactions within the root POPLsn: their role in ion accumulation by plants. Bot Rev 46:75-99

Hu PJ, Qiu RL, Senthilkumar P, Jiang D, Chen ZW, Tang YT, Liu FJ (2009) Tolerance, accumulation and distribution of zinc and cadmium in hyperaccumulator Potentilla griffithii. Environ Exp Bot 66:317-325

Hu PJ, Yin YG, Ishikawa S, Suzui N, Kawachi N, Fujimaki S, Igura M, Yuan C, Huang JX, Li Z, Makino T, Luo YM, Christie P, Wu LH (2013) Nitrate facilitates cadmium uptake, transport and accumulation in the hyperaccumulator Sedum plumbizincicola. Environ Sci Pollut R 20:6306-6316

Kachenko AG, Singh B, Bhatia NP, Siegele R (2008) Quantitative elemental localisation in leaves and stems of nickel hyperaccumulating shrub Hybanthus floribundus sub sp floribundus using micro-PIXE spectroscopy. Nucl Instrum Meth B 266:667-676

Koren S, Arčon I, Kump P, Nečemer M, Vogel-Mikuš K (2013) Influence of $\mathrm{CdCl}_{2}$ 
and $\mathrm{CdSO}_{4}$ supplementation on $\mathrm{Cd}$ distribution and ligand environment in leaves of the Cd hyperaccumulator Noccaea (Thlaspi) praecox. Plant Soil 370:125-148

Krämer U (2010) Metal Hyperaccumulation in plants. Annu Rev Plant Biol 61:517-534

Küpper H, Lombi E, Zhao FJ, McGrath SP (2000) Cellular compartmentation of cadmium and zinc in relation to other elements in the hyperaccumulator Arabidopsis halleri. Planta 212:75-84

Küpper H, Zhao FJ, McGrath SP (1999) Cellular compartmentation of zinc in leaves of the hyperaccumulator Thlaspi caerulescens. Plant Physiol 119:305-311

Li TQ, Yang XE, Yang JY, He ZL. 2006. Zn Accumulation and subcellular distribution in the $\mathrm{Zn}$ hyperaccumulator Sedum alfredii Hance. Pedosphere 16:616-623

Li Z, Wu LH, Hu PJ, Luo YM, Christie P (2013) Copper changes the yield and cadmium/zinc accumulation and cellular distribution in the cadmium/zinc hyperaccumulator Sedum plumbizincicola. J Hazard Mater 261:332-341

Lichtenberger O, Neumann D (1997) Analytical electron microscopy as a powerful tool in plant cell biology: Examples using electron energy loss spectroscopy and X-ray microanalysis. Eur J Cell Biol 73:378-386

Lin M, Qiang G, Pei CM, Xiao XT (2013) Accumulation and tolerance characteristics of zinc in Agropyron cristatum plants exposed to zinc-contaminated soil. B Environ Contam Tox 91:298-301

McGrath SP, Zhao FJ, Lombi E (2002) Phytoremediation of metals, metalloids, and radionuclides. Adv Agron 75:1-56

Nriagu JO, Pacyna JM (1988) Quantitative assessment of worldwide contamination of air, water and soils by trace metals. Nature 333:134-139

Ramos I, Esteban E, Lucena JJ, Gárate A (2002) Cadmium uptake and subcellular distribution in plants of Lactuca sp. Cd-Mn interaction. Plant Sci 162:761-767

Ryan CG, Cousens DR, Sie SH, Griffin WL (1990a). Quantitative Analysis of PIXE Spectra in Geoscience Applications. Nucl Instrum Meth B 49:271-276

Ryan CG, Cousens DR, Sie SH, Griffin WL, Suter GF, Clayton E (1990b) Quantitative PIXE micro analysis of geological material using the CSIRO proton microprobe. Nucl Instrum Meth B 47:55-71

Schwartz C, Echevarria G, Morel JL (2003) Phytoextraction of cadmium with Thlaspi caerulescens. Plant Soil 249:27-35

Sridhar BBM, Diehl SV, Han FX, Monts DL, Sub Y (2005) Anatomical changes due to uptake and accumulation of $\mathrm{Zn}$ and $\mathrm{Cd}$ in Indian mustard (Brassica juncea). Environ Exp Bot 54:131-141

Sun YB, Zhou QX, Wang L, Liu WT (2009) Cadmium tolerance and accumulation characteristics of Bidens pilosa L. as a potential Cd-hyperaccumulator. J Hazard Mater 161:808-814

Tian SK, Lu LL, Labavitch J, Yang XE, He ZL, Hu HN, Sarangi R, Newville M, Commisso J, Brown P (2011) Cellular sequestration of cadmium in the hyperaccumulator plant species Sedum alfredii. Plant Physiol 157:1914-1925

Vázquez MD, Barceló J, Poschenrieder C (1992) Location of zinc and cadmium in Thlaspi caerulescens (Brassicaceae), a metallophyte that can hyperaccumulate both metals. Plant Physiol 140:350-355

Vögeli-Lange R, Wagner GJ (1990) Subcellular localization of cadmium and cadmium-binding peptides in tobacco leaves. Plant Physiol 92:1086-1093

Vogel-Mikuš K, Regvar M, Mesjasz-Przybyłowicz J, Przybyłowicz WJ, Simčič J, Pelicon P, Budnar M (2008) Spatial distribution of cadmium in leaves of metal hyperaccumulating Thlaspi praecox using micro-PIXE. New Phytol 179:712-721 
Wang X, Liu YG, Zeng GM, Chai LY, Song XC, Min ZY, Xiao X (2008) Subcellular distribution and chemical forms of cadmium in Bechmeria nivea (L.) Gaud. Environ Exp Bot 62:389-395

Weigel HJ, Jäger HJ (1980) Subcellular distribution and chemical form of cadmium in bean. Plant Physiol 65:480-482

Wu LH, Liu YJ, Zhou SB, Guo FG, Bi D, Guo XH, Baker AJM, Smith JAC, Luo YM (2013) Sedum plumbizincicola X.H. Guo et S.B. Zhou ex L.H. Wu (Crassulaceae): a new species from Zhejiang Province, China. Plant Syst Evol 299:487-498 


\section{University Library}

\section{- MINERVA \\ A gateway to Melbourne's research publications}

Minerva Access is the Institutional Repository of The University of Melbourne

Author/s:

Cao, D;Zhang, H;Wang, Y;Zheng, L

Title:

Accumulation and Distribution Characteristics of Zinc and Cadmium in the Hyperaccumulator Plant Sedum plumbizincicola

Date:

2014-08-01

Citation:

Cao, D., Zhang, H., Wang, Y. \& Zheng, L. (2014). Accumulation and Distribution Characteristics of Zinc and Cadmium in the Hyperaccumulator Plant Sedum plumbizincicola. BULLETIN OF ENVIRONMENTAL CONTAMINATION AND TOXICOLOGY, 93 (2), pp.171-176. https://doi.org/10.1007/s00128-014-1284-8.

Persistent Link:

http://hdl.handle.net/11343/283278 